\title{
Human olfaction: a constant state of change-blindness
}

\author{
Lee Sela $\cdot$ Noam Sobel
}

Received: 18 January 2010 / Accepted: 21 June 2010 / Published online: 7 July 2010

(C) The Author(s) 2010. This article is published with open access at Springerlink.com

\begin{abstract}
Paradoxically, although humans have a superb sense of smell, they don't trust their nose. Furthermore, although human odorant detection thresholds are very low, only unusually high odorant concentrations spontaneously shift our attention to olfaction. Here we suggest that this lack of olfactory awareness reflects the nature of olfactory attention that is shaped by the spatial and temporal envelopes of olfaction. Regarding the spatial envelope, selective attention is allocated in space. Humans direct an attentional spotlight within spatial coordinates in both vision and audition. Human olfactory spatial abilities are minimal. Thus, with no olfactory space, there is no arena for olfactory selective attention. Regarding the temporal envelope, whereas vision and audition consist of nearly continuous input, olfactory input is discreet, made of sniffs widely separated in time. If similar temporal breaks are artificially introduced to vision and audition, they induce "change blindness", a loss of attentional capture that results in a lack of awareness to change. Whereas "change blindness" is an aberration of vision and audition, the long inter-sniff-interval renders "change anosmia" the norm in human olfaction. Therefore, attentional capture in olfaction is minimal, as is human olfactory awareness. All this, however, does not diminish the role of olfaction through sub-attentive mechanisms allowing subliminal smells a profound influence on human behavior and perception.
\end{abstract}

Keywords Olfaction · Awareness · Attention - Spatial · Temporal

L. Sela $\cdot$ N. Sobel $(\bowtie)$

Department of Neurobiology,

The Weizmann Institute of Science,

Rehovot 76100, Israel

e-mail: noam.sobel@weizmann.ac.il

\section{Introduction}

Mammalian olfaction is highly conserved (Ache and Young 2005). Indeed, the human olfactory system is not very different from that of goats and guinipigs. That said, the place of olfaction in human behavior is different, and seemingly largely diminished in comparison to most mammals (Stevenson 2009a). In this review we will propose two mechanistic reasons for this state of affairs. Beforehand, however, we will briefly outline human olfactory neuroanatomy, and human olfactory capabilities.

\section{Human olfactory neuroanatomy}

Like all mammalian olfactory systems, the human olfactory system follows a stereotyped anatomy consisting of three primary processing stages: The olfactory epithelium, the olfactory bulb, and olfactory cortex (Price 1990) (Fig. 1). The system is of course bilateral, containing two of each of these structures. Whereas until recently it was thought that the system is characterized by ipsilateral connectivity only, e.g., connectivity from left epithelium to left bulb to left cortex, recent functional evidence suggests that connectivity to cortex may follow contralateral pathways as well (McBride and Slotnick 1997; Wilson 1997; Savic and Gulyas 2000; Uva and de Curtis 2004; Porter et al. 2005; Cross et al. 2006).

Before an odorant is processed in this system, however, it must first be acquired. This acquisition is through sniffing, an active and critical sampling of the olfactory environment (Kepecs et al. 2006; Mainland and Sobel 2006; Schoenfeld and Cleland 2006) Notably, odorants can also be acquired through the mouth, a path referred to as retronasal olfaction (Heilmann and Hummel 2004; Small 


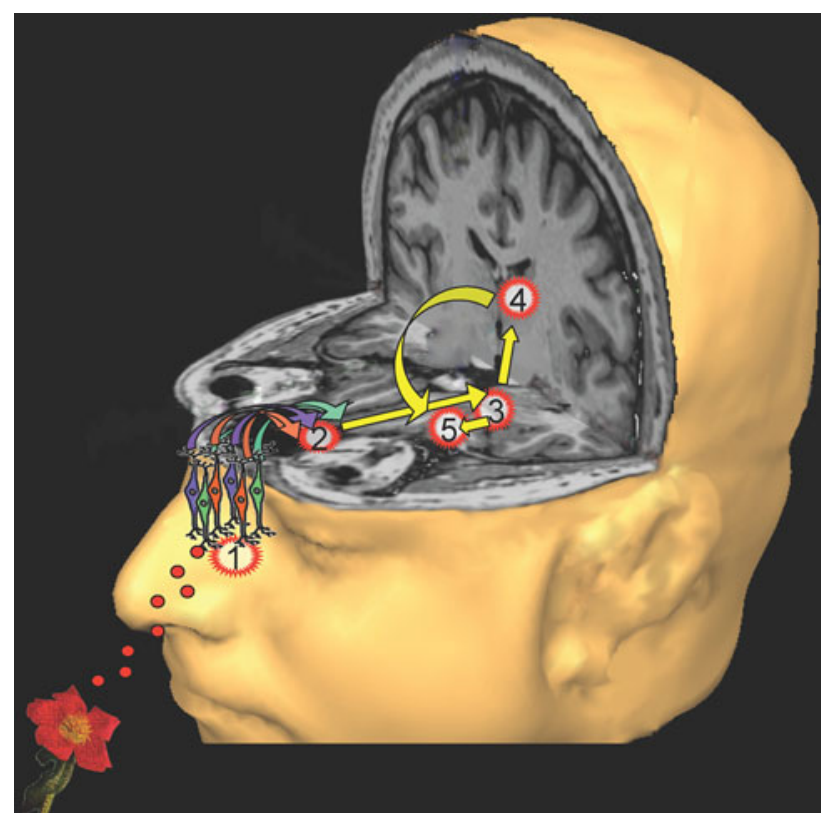

Fig. 1 Schematic of the human olfactory system. Odorants are transduced at the olfactory epithelium (1). Different receptor types (three illustrated, 1,000 in mammals) converge via the olfactory nerve onto common glomeruli at the olfactory bulb (2). From here information is conveyed via the lateral olfactory tract to primary olfactory cortex (3). From here, information is further relayed throughout the brain, most notably to orbitofrontal cortex (5) via a direct and indirect route through the thalamus (4)

et al. 2005; Hummel et al. 2006a). Sniffing not only carries the stimulus, but also drives patterns of neural activity throughout the olfactory system (Sobel et al. 1998a, b; Scott 2006; Verhagen et al. 2007). This sniff-driven activity may partly reflect an often-overlooked property of olfactory receptors, namely their possible dual-function as mechanoreceptors that sense air flow (Adrian 1942; Grosmaitre et al. 2007).

Once an odorant molecule is sniffed, it acts as a ligand for olfactory receptors that line the olfactory epithelium. These receptors are 7-transmembrane G-protein coupled second-messenger receptors where a cascade of events that starts with odorant binding culminates in the opening of cross-membrane cation channels that depolarize the cell (Spehr and Munger 2009). The mammalian genome contains more than 1,000 such receptor types (Buck and Axel 1991), yet humans functionally express only $\sim 400$ of these (Gilad and Lancet 2003). Humans have $\sim 12$ million bi-polar receptor neurons in each epithelium (Moran et al. 1982), and these neurons differ from typical neurons in that they constantly regenerate from a basal cell layer throughout the lifespan (Graziadei and Monti Graziadei 1983). Typically, each receptor neuron expresses only one receptor type, although recent evidence from Drosophila has suggested that in some cases a single neuron may express two receptor types (Goldman et al. 2005). Each receptor is typically responsive to a small subset of odorants (Malnic et al. 1999; Hallem and Carlson 2006; Saito et al. 2009), although some receptors may be responsive to only very few odorants (Keller et al. 2007), and other receptors may be responsive to a very wide range of odorants (Grosmaitre et al. 2009). This receptor odorant specificity is considered the basis for olfactory coding (Su et al. 2009).

Whereas receptor types appear largely dispersed throughout the olfactory epithelium, the path from epithelium to bulb via the olfactory nerve entails a unique pattern of convergence that brings together all receptor neurons that express a particular receptor type. These synapse onto one of two common points at the olfactory bulb termed glomeruli. Thus, the number of glomeruli is expected to be about double the number of receptor types, and the receptive range of a glomerulus is expected to reflect the receptive range of a given receptor type. Whereas these rules have been learned mostly from studies in rodents, the human olfactory system may be organized slightly differently, as rather than the expected $\sim 750$ glomeruli (about double the number of expressed receptor types), postmortem studies revealed many thousands of glomeruli in the human olfactory bulb (Maresh et al. 2008).

The olfactory bulb is largely considered the seat of olfactory identity coding. The common notion is that an odorant is represented in the spatiotemporal pattern of activated glomeruli (Leon and Johnson 2003; Su et al. 2009). That said, such a spatiotemporal code has yet to be linked to meaningful olfactory information (Mainen 2006). In other words, despite the development of recent methods to characterize odorants (Haddad et al. 2008a, b), there is still no key that would allow looking at a bulbar spatiotemporal activation pattern and determining what odorant generated it.

From the bulb, olfactory information is projected to primary olfactory cortex via the olfactory tract. Primary olfactory cortex inhabits large portions of the ventral temporal lobe, and its primary component is the piriform cortex (Price 1990). Not much is known on how odorants are represented in cortex. However, a recent rodent study has found that cells with similar receptive fields are highly distributed across piriform cortex (Stettler and Axel 2009). In other words, similar odorants are not likely to activate adjacent cells. Moreover, a growing body of research using functional imaging in humans points to the role of the piriform cortex in odor classification and differentiation (Li et al. 2006, 2008; Howard et al. 2009). In turn, a role for piriform cortex in the generalization processes that allow the stability of olfactory perception has also been identified. For example, an ensemble of piriform neurons responded similarly to a mixture of 10 odors and to a mixture including 9 of the 10 odors, but responded differently when one of the 10 odors was replaced with a novel odor (Barnes et al. 2008). 
In other words, piriform cortex responded similarly to an odor and a degraded version of the same odor, but responded differently to what was potentially a novel odor source, despite overall chemical similarity. With all this in mind, it is interesting that in contrast to the well documented phenomena of cortical blindness and deafness, we know of no case of cortical anosmia, that is, a complete loss of smell following a focal cortical lesion although there are known cases of sub-cortical anosmia as in the case of Kallmann Syndrome that affects the olfactory bulb (Madan et al. 2004; Fechner et al. 2008). This alone poses restrictions on the functional role of primary olfactory cortex.

Beyond primary olfactory cortex, olfactory information is distributed widely throughout the brain. Notable in this respect is the orbitofrontal cortex that is largely considered secondary olfactory cortex (Price 1990), as is the issue of thalamic connectivity: Whereas other sensory modalities traverse a thalamic relay en route from periphery to primary cortex, in olfaction information reaches primary cortex directly. This is not to say, however, that there is no olfactory thalamic pathway. A recent lesion study has implicated thalamic involvement in olfactory identification, hedonic processing, and olfactomotor control (Sela et al. 2009), and a recent imaging study has implicated a thalamic role in olfactory attention (Plailly et al. 2008).

Finally, it is noteworthy that the nose contains several additional subsystems beyond the olfactory receptors that are also capable of transducing airborne molecules (Breer et al. 2006). Of these, most notable are the trigeminal nerve endings. Most odorants will induce at least some trigeminal activation, and only very few identified "pure olfactants" will stimulate the olfactory nerve alone (Doty 1995). Macrosmatic mammals also have an accessory olfactory system with its sensory epithelium in the vemoronasal organ (Keverne 1999), as well as additional chemosensing subsystems such as the septal organ (Kaluza et al. 2004; Tian and Ma 2004) and Gruenberg organ (Fleischer et al. 2006). The existence of these structures in humans, however, remains unclear (Meredith 2001; Witt and Hummel 2006).

\section{Humans have a superb sense of smell}

Given that humans are endowed with a typical mammalian olfactory system, one may question what humans can do with this hardware. As we have recently reviewed elsewhere (Yeshurun and Sobel 2010), humans indeed have an extraordinary, if underappreciated, sense of smell (Shepherd 2004; Zelano and Sobel 2005). For example, humans can detect the scent of fear in human sweat (Chen and Haviland-Jones 2000; Ackerl et al. 2002), and may select mates who's body-odor infers a favorable genetic makeup (Wedekind and Furi 1997). Such behaviors can depend on keen human olfactory detection. For example, the odorant ethyl mercaptan that is often added to propane as a warning agent, can be detected at concentrations ranging between $0.2 \mathrm{ppb}$ (parts per billion) (Whisman et al. 1978) and $0.009 \mathrm{ppb}$ (Nagata 2003). This is equivalent to approximately three drops of odorant within an Olympicsize swimming pool-given two pools, a human could detect by smell which pool contained the three drops of odorant. Extremely low detection thresholds have been reported for the odorants d-limonene and ozone as well (Cain et al. 2007). Finally, the lowest human detection threshold we are aware of is for isoamyl mercaptan reported at 0.77 parts per trillion (Nagata and Takeuchi 1990).

Humans are not only inherently good at odorant detection; they can further improve with practice. Repeated exposure to an odorant leads to decreased detection thresholds for a number of different odorants (Engen and Bosack 1969; Cain and Gent 1991; Dalton et al. 2002). Furthermore, humans who were completely unable to detect the odor of androstenone developed the ability to detect it after repeated exposure (Wysocki et al. 1989). There is an ongoing debate as to the location of plasticity underlying these improvements: Whereas some studies implicate plasticity at the olfactory epithelium (Yee and Wysocki 2001; Wang et al. 2004), other studies suggest a cortical mechanism of plasticity (Mainland et al. 2002). The recent identification of the specific human olfactory receptor that is primarily responsible for the detection of androstenone (Keller et al. 2007) may now enable a more direct investigation of this question.

Humans are not only good at detecting odorants, they are also good at discriminating one odorant from another, either in terms of concentration or molecular identity. Humans can discriminate between two odorants that differ in concentration by as little as $7 \%$ (the olfactory "just noticeable difference") (Cain 1977), and even smaller changes in the relative proportion of a component in a mixture can change the perception of the mixture (Le Berre et al. 2008). Humans can also discriminate the smallest alterations in molecular structure, such as between odorants equal in number of carbons but differing in functional group (Laska et al. 2000), or equal in functional group but differing in chain length by one carbon only (Laska and Freyer 1997). Moreover, humans are able to discriminate between various pairs of enantiomers (mirror-image molecules) such as (+) and (-) carvone (Laska et al. 1999).

The most impressive cases of human olfactory discrimination involve odorants that are ecologically meaningful. For example, human participants could use smell to discriminate their own T-shirt from 100 identical T-shirts worn by others for $24 \mathrm{~h}$ (Lord and Kasprzak 1989). Human mothers could discriminate between the smell of their baby and other babies (Porter et al. 1983). Five- to eight-year-old 
children could discriminate between the smell of their three- to four-year-old siblings and other children (Porter and Moore 1981), and 9-year-old children could discriminate between the smell of their close friends (Mallet and Schaal 1998). Furthermore, these discriminatory powers may be innate: Babies can discriminate the smell of their breast-feeding mothers from other mothers by 6 days after birth (Macfarelane 1975; Schaal et al. 1980), and newborn babies cry less when exposed to the odor of amniotic fluid (which was present in the intrauterine environment) than to the odor of their mother's breasts (Varendi et al. 1998). Breast-feeding infants, at approximately 2 weeks of age, discriminated between their mother's axillary odor and odors produced by either nonparturient or unfamiliar lactating women (Cernoch and Porter 1985).

Like odorant detection, odorant discrimination can improve with learning and practice (Rabin 1988). Increased familiarization was associated with a decrease in discrimination errors of initially unfamiliar odors (Jehl et al. 1995). Odor enantiomers that were initially indiscriminable became discriminable after one of the enantiomers was associated with an electric shock (Li et al. 2008). Subjects working in perfume retail outlets were significantly better at odor discrimination compared with subjects not working in such odorous environments (Hummel et al. 2004), and wine tasters were superior to naive controls at odor discrimination (Solomon 1990; Melcher and Schooler 1996; Bende and Nordin 1997; Parr et al. 2002).

Notably, across the above reviewed feats of olfactory detection and discrimination, women usually outperform men (Koelega and Koster 1974; Wysocki and Gilbert 1989; Hulshoff Pol et al. 2000; Choudhury et al. 2003), and performance declines with age starting at about the age of 40 (Cain and Stevens 1989; Murphy et al. 2002; Rawson 2006).

\section{Humans don't trust their nose}

Despite possessing a first-rate chemical detector, humans appear to both underrate it and mistrust it. Indeed, many of the above detailed feats of olfactory discrimination were achieved despite low confidence (Lundstrom et al. 2008). This mistrust is reflected in both direct and indirect measures. For example, a survey of college students found that olfaction was overwhelmingly classified as the least important human sense (Classen et al. 1994). This common approach is reflected in legislation: the American Medical Association has determined that whereas loss of vision or audition constitutes an 85 and $35 \%$ impairment respectively, loss of olfaction constitutes a $3 \%$ impairment only (AMA 1993). Furthermore, humans are very poor at assessing their own acuity. For example, there was no correlation between olfactory detection thresholds and self-ratings of olfactory abilities (Philpott et al. 2006). In a replication of this result, self-ratings again didn't correlate with abilities, but did correlate with "odor annoyance" (Knaapila et al. 2008). In other words, people who notice odors and are annoyed by them, therefore think that they have a better sense of smell, yet in fact they don't. They simply pay more attention to smell. This state of affairs can be modified: when subjects were first asked to rate their sense of smell and were then tested, there was again no correlation between self-ratings and performance. However, when subjects were first tested and then subsequently asked to rate their sense of smell, a significant correlation emerged (Landis et al. 2003). In other words, an acute and implicit demonstration (the test) was sufficient to enlighten participants as to their true olfactory prowess.

\section{Humans don't notice smells}

Taken together, the above studies suggest that humans are disconnected from their own abilities in olfaction. This explicit underrating is further reflected indirectly: In a task that was described to participants as an "examination of different sensory conditions on judgments about art", the only sensory condition that was in fact manipulated was odor. Participants were instructed to rate the appeal of neutral pictures presented in a room scented with either vanilla or lavender. Participants were later asked whether they noticed which sensory modality was manipulated. Whereas numerous participants reported a perceived (although nonexistent) manipulation in luminance, only 3 of 93 reported a manipulation of smell (Lorig 1992).

Furthermore, when humans obtain conflicting information from their nose and eyes, they trust their eyes, even in decidedly olfactory tasks. For example, adding color to an odorless solution increased the probability of assigning an odor to the solution (Engen 1972). Similarly, coloring a cherry-flavored drink in orange rendered it as having an orange or apricot flavor, and also, coloring the same drink in green rendered it as lime or lemon flavor (Dubose et al. 1980). Strikingly (and embarrassingly), even "olfactory experts" are not immune to visual dominance in olfactory decisions: A panel of 54 students of Oenology shifted to assigning red wine descriptors to white wine that was colored with an odorless red (Morrot et al. 2001).

The above studies combine to reveal that humans go largely unaware of their olfactory environment and therefore underestimate their olfactory abilities. This is punctuated by the standards applied to the use of odorants as warning agents. Whereas the detection threshold for ethyl mercaptan is as low as $0.009 \mathrm{ppb}$ (Nagata and Takeuchi 1990), it is introduced as a warning agent to propane at 
0.5 ppm, i.e., $\sim 57,000$ times its detection threshold. Herein lies the paradox. Humans have a superb sense of smell, they can detect ethyl mercaptan at exceedingly low concentrations, yet it takes 57,000 times threshold in order to spontaneously shift attention to olfaction. Why?

\section{No space for human olfactory attention}

Humans, like all mammals, function in an environment packed with countless stimuli. Mechanisms of selective attention have evolved to cope with this mass of information (James 1890; Broadbend 1958). These mechanisms allow focusing of processing resources on environmental features that were selected, either according to the salience of the objects or by volitional intention. The primary distal sense in humans is vision. In that vision is inherently spatial (DeValois and DeValois 2002), selective attention has evolved to allow allocation of attention in space. A socalled "attentional spotlight" can be directed with extreme spatial precision to allow heightened processing for events at selected locations (Posner et al. 1980). Moreover, this spotlight can be overtly directed in external space, or covertly directed in an internal analogue-space. Whereas the former is clearly evident in behaviors such as shifting of gaze, the latter was revealed in experiments where a spatial cue improved performance in the cued location despite no shifting of the actual gaze (Posner and Petersen 1990). Such spatial attention is similarly evident in audition (Salmi et al. 2007). Humans have superb spatial abilities in audition (Bregman 1990), and auditory acuity can be heightened for a particular location in space by shifting attention towards that location (Hafter 1984; Robin and Rizzo 1992; Spence and Driver 1994; Driver and Spence 2004). Similar to vision, such shifting can take place in external space by directing the ears towards the area of interest, or in an internal analogue auditory space, where similar to vision a spatial cue improves auditory performance in the cued location despite no redirection of the ears (Fritz et al. 2007). Notably, mechanisms of selective attention are activated in proximal senses as well (e.g., tactile perception (Driver and Grossenbacher 1996; Spence 2002; Driver and Spence 2004), and gustation (Veldhuizen et al. 2007; Grabenhorst and Rolls 2008)), yet here we will restrict our review to distal sensing alone.

In contrast to the superb human spatial abilities in vision, and audition, humans have only rudimentary spatial abilities in olfaction. A critical distinction in spatial abilities is between egocentric and allocentric space. As these terms can be used differently by different researchers (Klatzky 1998), we will clearly state our use of these terms here: By allocentric abilities, we are referring to a spatial representation obtained through movement, whether of the nose alone or the entire body, within the olfactory environment. As anybody who has located a spoiled food source in the refrigerator knows, humans do have allocentric olfactory spatial abilities. Furthermore, these can be refined with practice. For example, we have found that humans can learn to track a scent-trail in a field (Fig. 2a), and they significantly improve their performance at this task with each of only four practice sessions (Porter et al. 2007) (Fig. 2b).

In turn, by egocentric olfactory spatial abilities, we are referring to an olfactory representation of coordinate space despite a fixed nose. Whereas macrosmatic mammals most likely have such abilities that rely on cross-nostril comparisons (Rajan et al. 2006), humans may enjoy only rudimentary egocentric olfactory representation. This question was initially studied by Von Bekesy, who had previously conducted pioneering studies on auditory spatial processing (Békésy 1964). Von Bekesy generated olfactory stimuli with precise spatial and temporal control, and determined that human subjects could egocentricly localize an odorant to within 7 to 10 spatial degrees, and that this localization depended on time-of-arrival or concentration differences across nostrils. This astonishing result, however, was never successfully replicated. As previously noted, many odorants can contain a trigeminal component that excites the trigeminal nerve. Several studies suggested that the Von Bekesy result reflected use of trigeminal rather than pure olfactory stimuli, and that when using pure olfactants that do not stimulate the trigeminal nerve humans could not even tell whether the odorants were coming from the left or from the right, let alone localize them to within 7 to 10 degrees (Schneider and Schmidt 1967; Kobal et al. 1989; Radil and Wysocki 1998; Frasnelli et al. 2009). In our studies of this question we found that humans could in fact distinguish left from right even when using pure olfactory stimuli, but performance was only slightly yet significantly above chance (Porter et al. 2005) (Fig. 2c). Furthermore, we found a nostril-specific representation in piriform cortex similar to that found in rats (Wilson 1997), which may combine with additional brain mechanisms (Fig. 2d) to provide a neural substrate for such localization.

The above studies combine to suggest that human egocentric olfactory representation is minimal at best. Given that humans have no external allocentric olfactory coordinate space, they obviously don't have an internal analogue olfactory coordinate space. Thus, humans do not have a spatial arena in which to direct olfactory selective attention, and this renders olfactory attention profoundly different from visual and auditory attention.

Attention, however, is not directed in coordinate space alone. In both vision and audition, attention can also be directed in stimulus space. Such attentional selectivity allows extraction of salient signals from the complex and noisy background. For example, in audition, the cocktail 
Fig. 2 No space for human olfactory attention. a Results from Porter et al. (2007).

Humans have good allocentric olfactory abilities, and can follow a scent trail. b Scent-trail tracking speed increases with each of 4 days of practice. c Results from Porter et al. (2005). Humans have poor egocentric olfactory abilities, and are only marginally but significantly above chance at localizing the pure olfactant PEA to either the left or right of the nose. Note significantly better performance for propionic acid that has a significant trigeminal component. D. Brain mechanisms involved in extracting spatial information from smell, including the superior temporal gyrus
A

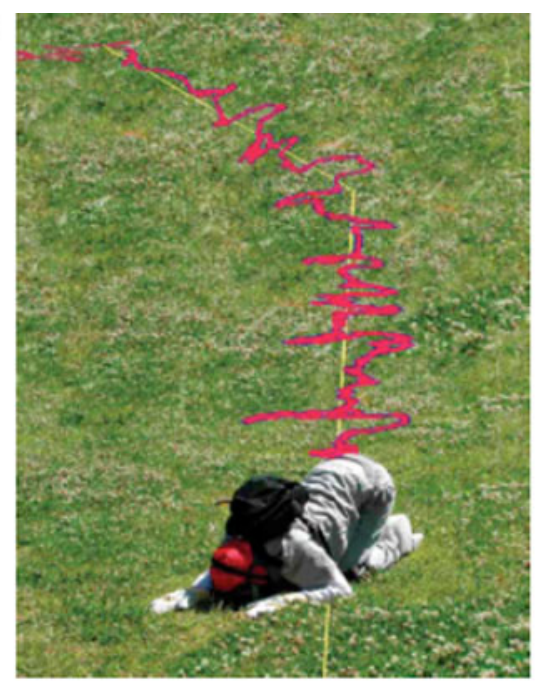

B

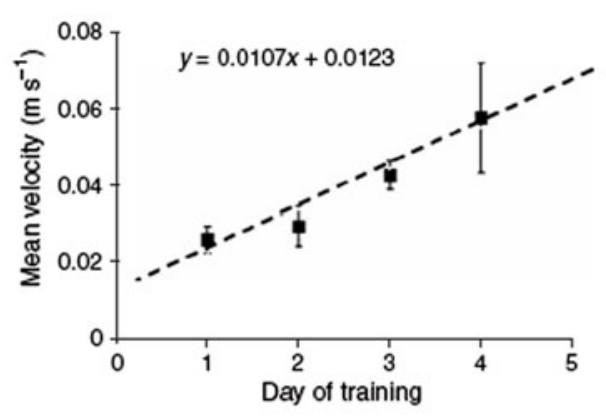

C
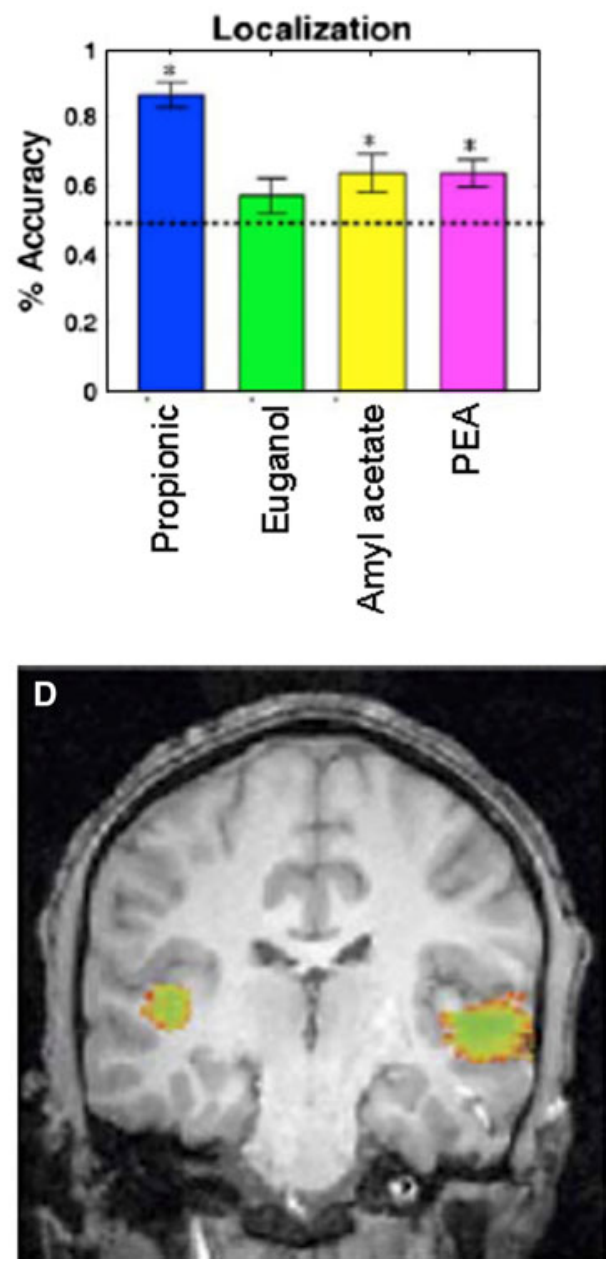

party effect (Cherry 1953) refers to the remarkable human ability to detect and selectively attend to a specific source of auditory input in a noisy environment. The guidance of attention can be exogenous (unintentional directing of attention to a salient event), as when hearing your name in a loud party automatically directs attention to the source, or endogenous (intentionally guidance of attention to a particular event or spatial location), as when deciding to try and "listen in" for a particular voice at the same party. Similar exogenous and endogenous mechanisms allow the focusing of attention within visual (Treisman and Gelade 1980) stimulus space as well.

Such stimulus-space based attention, however, is again minimal in olfaction. For example, when trying to identify a component in a mixture, subjects performed equally well whether they simply tried to identify all the components in the mixture, or were first exposed to the target component and tried to determine whether it alone was present or absent in the mixture (Laing and Glemarec 1992). In other words, this and similar results (Laing and Francis 1989; Livermore and Laing 1996) suggest that unlike in vision and audition, an effort to direct attention towards a specific aspect of stimulus space did not improve performance in olfaction. To relate this poor ability in stimulus-space to the near rudimentary ability in coordinate-space, it is noteworthy that when attending within visual and auditory stimulus-space, the object of attention nevertheless does have spatial coordinates, even if those are not the object of the attentional focus. It may be that such coordinate location is critical for attentional mechanisms, even when tuned to stimulus attributes (Deouell et al. 2007). As noted, in human olfaction coordinate space is rudimentary, and whereas this will clearly limit olfactory coordinate-space attention, it may also limit olfactory stimulus-space attention.

All this, however, is not to say that there is no olfactory attention at all. Whereas there is scant evidence for attention in olfaction, there are several demonstrations of attention to olfaction. For example, when making intensity discriminations in both vision and olfaction, olfactory discriminations were faster when an explicit cue first directed the subject's attention to olfaction (Spence et al. 2001). 
Such directing of attention to olfaction is reflected in both global and focal measures of brain activity. Globally, recording of olfactory event-related potentials (OERPs) suggested that attending to odors reduced latency for an early OERP component (Krauel et al. 1998), and increased amplitude for a later OERP component (Pause et al. 1997; Krauel et al. 1998; Geisler and Murphy 2000). Locally, brain-imaging studies found that activity in several brain structures reflected directing of attention to olfaction. These include the earliest levels of cortical processing, such as piriform cortex and olfactory tubercle, where sniff-induced activity was altered by the expectation of odor alone (Zelano et al. 2005). Furthermore, activity in downstream structures was further modulated as a function of expected odor content (de Araujo et al. 2005). Attention to olfaction also augmented the functional interaction between the posterior piriform cortex and the orbitofrontal cortex through the mediodorsal nucleus of the thalamus (Plailly et al. 2008).

To conclude this section, one reason for minimal human awareness of olfaction may be the nature of selective attention in olfaction. Human olfaction is characterized by minimal spatial abilities. Given no external olfactory coordinate space, there is therefore no internal analogue olfactory coordinate space, hence no arena for olfactory spatial selective attention. Although this reduced attention in olfaction does not prevent mechanisms of attention to olfaction, it nevertheless likely influences the place of olfaction in human awareness.

\section{No time for human olfactory attention}

The distal senses of vision, audition, and olfaction differ not only in their ability to produce an internal representation of external space, but also in their temporal envelope. Audition consists of an essentially continuous sampling of the sensory content. Vision similarly entails nearly continuous sampling broken only by occasional blinks, a short lived loss of input on the order of $250 \mathrm{~ms}$ (Caffier et al. 2003). Rapid eye movements termed saccades and microsaccades may also entail brief loss of input, although this remains unclear (Burr et al. 1994). In contrast to this largely continuous input in vision and audition, the olfactory system acquires sensory information in temporally discrete quanta, namely sniffs. Olfactory information is made available to the brain during brief bursts followed by often prolonged periods of no input. These bursts are often rhythmic in macrosmatic mammals occurring at between 4 and $11 \mathrm{~Hz}$ (Welker 1964; Youngentob et al. 1987), yet are discreet in humans, who tend to use one or very few successive sniffs to explore olfactory content (Laing 1983) (Fig. 3). There has been extensive research on how this unique quantized
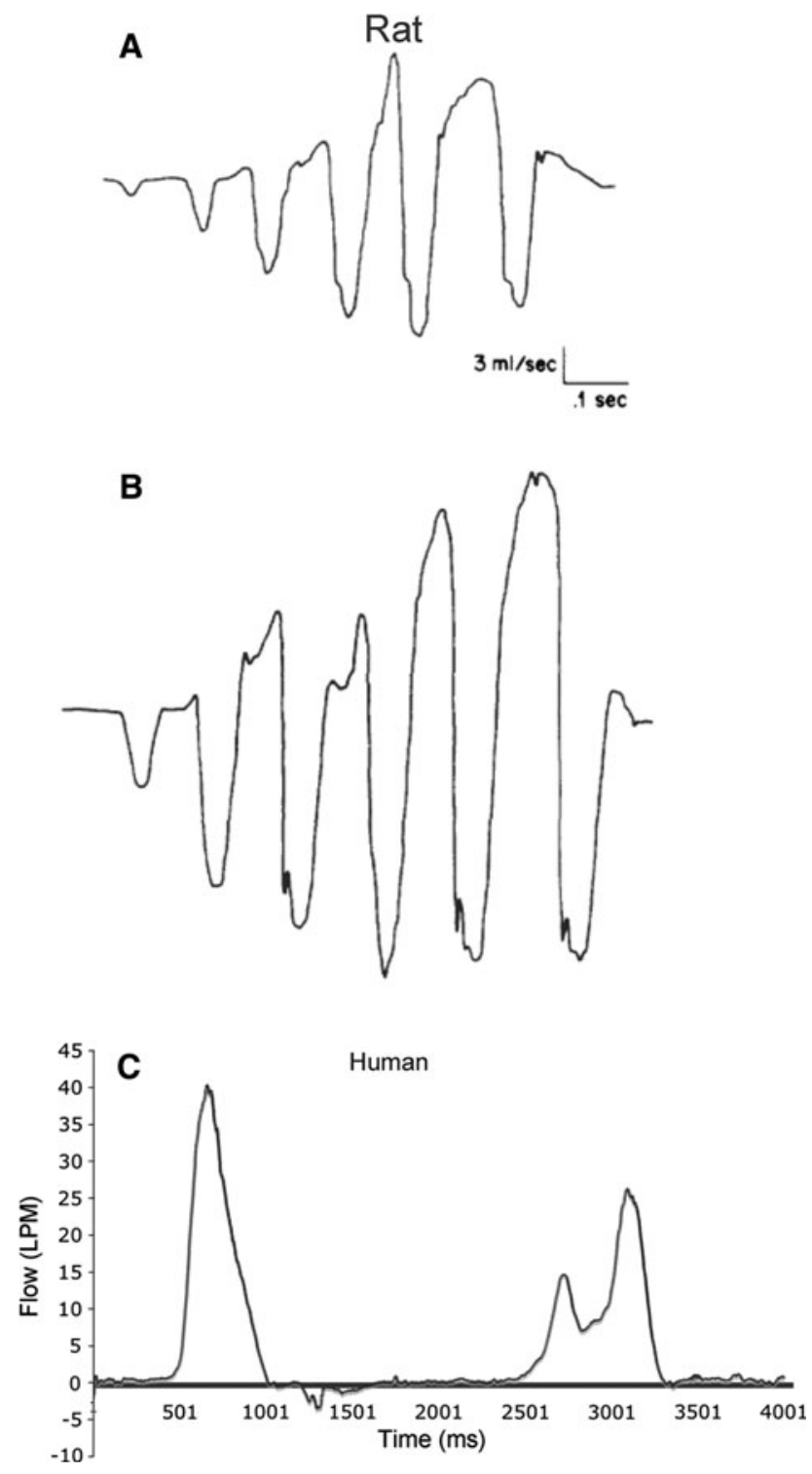

Fig. 3 No time for human olfactory attention. a, b. Results from Youngentob et al. (1987). Two typical sniff-traces from rats. Note the time-scale bar is at $0.1 \mathrm{~s}$. In other words, sniffing is portrayed at $\sim 9 \mathrm{~Hz}$ within the sniffing bout. $\mathbf{c}$ A typical sniff-trace from a human subject in our lab. The subject generated 2 sniffs in 4 s, i.e. $0.5 \mathrm{~Hz}$. The long delay between each sniff in the sniffing bout is sufficient in our view for change-anosmia

temporal envelope is reflected in the neural representation of olfaction (Sobel et al. 1998a; Kepecs et al. 2006; Mainland and Sobel 2006; Scott 2006; Verhagen et al. 2007). Here, we suggest that it is also this temporal dynamic that shaped the special place of olfaction in human awareness (awareness in this case refers to the ability of a person to consciously distinguish or detect an olfactory stimulus from the surrounding background). The basis for our claim rests on the phenomena of change blindness. Using vision, humans can detect even the slightest change in the visual scene, and this change detection can function as an 
orienting cue for attention. Furthermore, changes in a scene are often accompanied by transients such as motion. The motion signal attracts attention to the changed location, and in this way facilitates visual processing (Remington et al. 1992). For example, if one complex landscape image is instantaneously replaced by a second nearly identical landscape image with only one minor change, that change will mostly be detected with ease. Furthermore, visual attention will focus on the change location (Abrams and Christ 2003). However, if a temporal break is introduced between one image and the next, even significant changes in image content may go unnoticed. This phenomenon, termed change blindness (Rensink et al. 1997), can be experienced by the interested reader at several on-line demonstrations (e.g., http://www.psych.ubc.ca/ rensink/flicker/download/). Notably, a similar phenomenon occurs in audition (Vitevitch 2003; Eramudugolla et al. 2005; Wayand et al. 2005; Demany et al. 2008) and touch (Gallace et al. 2006; Auvray et al. 2008) as well. In other words, change blindness (or deafness) suggests that temporal continuity of input is key to awareness. As noted, human olfaction lacks temporal continuity, and therefore we argue that this has dictated a unique, and indeed extremely limited, place for olfaction in human awareness. As this claim is a major point in this review, we will reiterate by example: Look at Fig. 4, then look at a blank page, and then turn the page to look at Fig. 5. Do this such that the transition from Figs. 4, 5 takes a few seconds. Can you detect the change between figures? Such is human olfaction. A slow transition from one image (sniff) to the next, with a blank page inserted in between. Although change blindness may differ from the case of olfaction in that it requires an intentional search of the change in the scene, other features of change blindness, namely the inability to detect change in quantal as opposed to continuous information, provides a powerful analogy to the constant state of olfaction.

We suggest that these breaks in olfactory sampling result in change anosmia, a likely inability to spontaneously detect less than drastic changes in the olfactory natural space. Impaired olfactory change detection may, in turn, result in poor attention to olfaction. Indeed, the attentional mechanisms revealed in change-blindness are arguably the main path for non-volitional attention allocation to salient stimuli in the environment (Corbetta and Shulman 2002). We suggest here that due to a form of olfactory changeblindness, olfactory stimuli are less prone to attract attention, and therefore humans have poor awareness to the olfactory environment.

To this point we have delineated two aspects of human olfaction that may limit human awareness to smell. We argued that poor spatial abilities combined with discontinuous input over time together rendered a limited place for olfaction in human awareness. However, two studies that

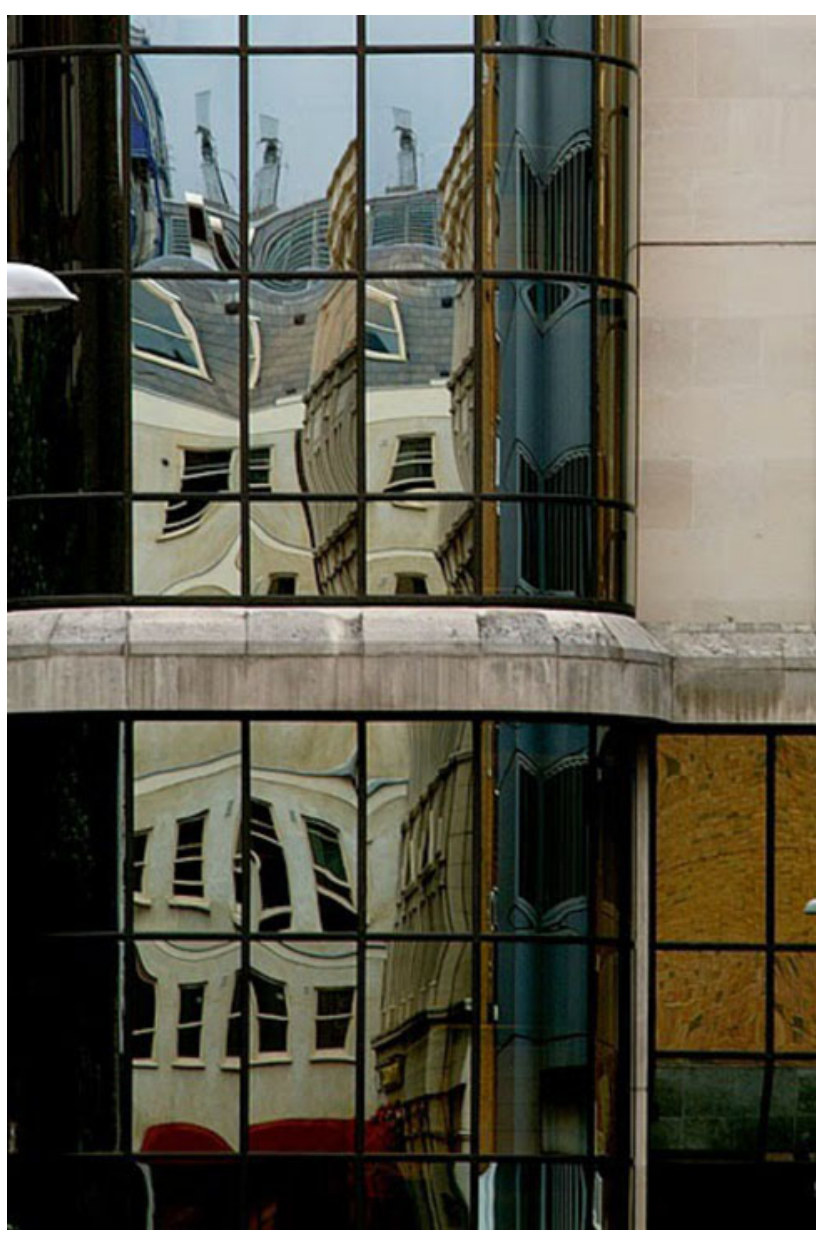

Fig. 4 Sniff 1. Carefully examine this picture, then look at a blank page, and then turn the page to look at Fig. 5

measured brain-responses in relation to olfactory attention suggest a more complicated situation. A classic attentional task is the odd-ball paradigm, where a repeating standard stimulus is periodically replaced with an infrequent deviant. This paradigm was adapted to olfaction using frequent and infrequent odorants in fMRI (Sabri et al. 2005) and OERP (Krauel et al. 1999) studies. In the fMRI study the paradigm was repeated under two conditions, an attend condition where attention was explicitly directed to olfaction, and an unattend condition where attention was directed to audition. The OERP study used an unattend condition only. Both studies found brain-responses to odorants in the unattend condition, i.e., when attention was focused on audition. In fact, the fMRI study revealed a more extensive odorant-change-induced response in the unattend compared to the attend condition (Sabri et al. 2005). In other words, even and perhaps especially when humans are unaware of odors, their brain clearly registers odorant change. This was further evidenced in electrophysiology and brain imaging studies that although not in the context of an attentional task, revealed that undetected odorants nevertheless induce 


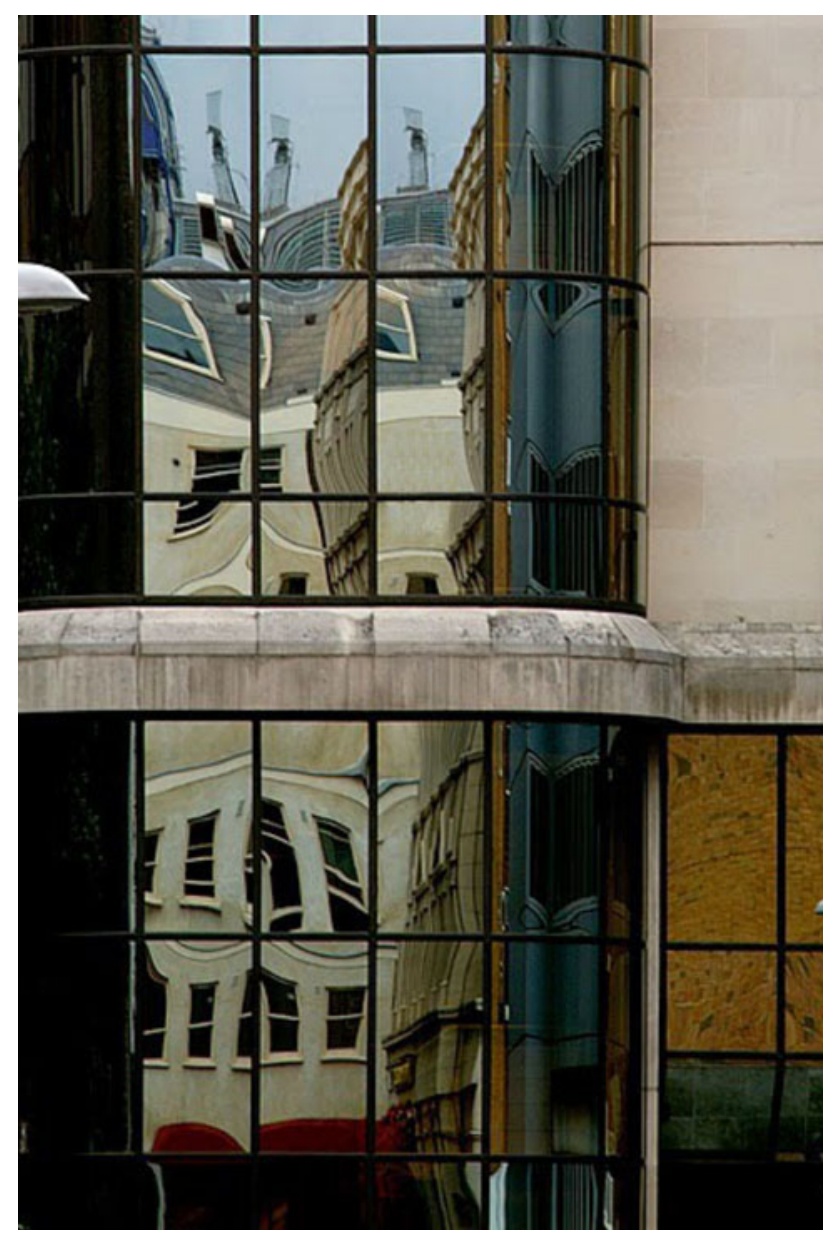

Fig. 5 Sniff 2 Do you see the change from sniff 1? Probably not. Such is human olfaction: discreet samples of sensory content separated by prolonged periods of no input. Now repeat rapidly without the intersniff-interval

neural activity at the olfactory epithelium (Hummel et al. 2006b) and cortex (Sobel et al. 1999; Jacob et al. 2001b).

Taken together, this suggests that in spite of the awareness-limiting settings we have proposed in relation to the spatial and temporal envelopes of olfaction, the human brain may nevertheless register the finest alterations in olfactory content, and these may significantly influence behavior. Indeed, in the previously described study where subjects were asked which sensory modality they thought was manipulated (Lorig 1992), anecdotally, one subject who was in the "vanilla" condition thought that luminance was manipulated, yet then stressed that she wants to go home to bake some cookies... Could it be that odorants that humans are unaware of continuously shape their behavior?

\section{The influence of subliminal odors}

The topic of subliminal odors immediately conjures up the topic of pheromones. Pheromones are odorants that are released by one member of a species to influence or signal other members of the same species (Karlson and Luscher 1959), yet nowhere in their classic definition does the issue of awareness arise. Indeed, pheromones were mostly studied in the context of non-human animals where awareness per se cannot be defined. Whether humans have pheromones is a topic of heated debate (Wysocki and Preti 2004), as is whether the term pheromone is at all helpful when considering odor-guided behavior (Doty 2003; Stowers and Marton 2005). For the purpose of this review, however, we choose to circumvent this often semantic debate altogether. We will detail cases where subliminal odorants influenced perception and behavior, and the existence of such influence is our interest regardless of whether one chooses to call the odorant a pheromone or ordinary odorant. That said, in cases where the odorant was derived from human bodily secretions, or is present in such secretions, in our mind suggests that these odorants may function as human chemosignals.

When considering evidence for the influence of odors without awareness one must make a distinction between two types of studies: In what we will call here Type A studies, participants were made aware of the focus on olfaction, or even of a particular odorant, yet not the odorant of interest that was typically masked within a perfume. There is an extremely large body of such studies. By contrast, in what we will call Type B studies, even the mere presence of odors was not explicitly revealed to participants. Type B studies, although limited in number, are particularly relevant to the attentional mechanisms (or lack thereof) we have proposed. Here we will focus on this latter type of study, with only reference to Type A studies.

\section{Subliminal odorants influence physiological state}

Women who live in close proximity and continuous interaction, such as roommates in female dormitories, tend to synchronize the timing of their menstrual cycle (McClintock 1971) (but see (Wilson 1992)). In that this occurs with no awareness of an olfactory signal, this dramatic effect clearly fits our criteria for Type B studies. However, one may question whether this effect was at all chemosignal dependent. Perhaps there was some nonchemical social signal at play? This was answered in a series of studies where experimenters obtained underarm sweat extracts from donor women during either the ovulatory or follicular menstrual phase. These extracts were then deposited on the upper lips of recipient women, where follicular sweat accelerated ovulation and ovulatory sweat delayed it (Russell et al. 1980; Stern and McClintock 1998). Whereas these latter studies were Type A, they verify that the initial Type B menstrual synchrony studies, where odorants were truly subliminal, were indeed 
olfactory. Menstrual synchrony remains the most clear-cut instance of subliminal odors influencing human physiology. Combined with numerous Type A studies where either sweat or individual components of sweat altered hormonal state (Preti et al. 2003; Wyart et al. 2007), brain activity (Savic et al. 2001, 2005; Savic 2002; Gulyas et al. 2004), and mood (Chen and Haviland-Jones 2000; Jacob et al. 2001a; Bensafi et al. 2004; Lundstrom and Olsson 2005), together suggest that human sweat contains compounds that function as human chemosignals.

Subliminal odorants influence social judgments

The earliest Type B study we know of assessed the effects of two odorants, androstenol (5a-16-androsten-3a-oi) and an aliphatic acid mixture, on what was described as the "assessment-of-people test", a battery of judgments made by participants on a fixed group of individuals posing as job candidates (Cowley et al. 1977). To hide the use of odors, the authors deceived their participants and told them to wear surgical face-masks in order to hide their own facial expressions from other participants, when in fact these face-masks were impregnated with the odorants. The results indicated significant opposing influences of the two odorants on judgments. These effects were restricted primarily to female participants, while making positive judgments, that were enhanced by androstenol and reduced by the aliphatic acid mixture.

In a more recent study that was closer to Type A than Type B, the appeal of human faces was estimated in the presence of one of three different odorants; the pleasant citral, the neutral anisole, and the unpleasant valeric acid (Li et al. 2007). The odorants were presented at very low concentrations. The subjects tried to smell the odorants (hence Type A), and then conducted the task. The hedonic value of the odorants altered the appeal of the faces, but only for those subjects who were unable to detect the odorants (Fig. 6a). In other words, consistent with the previously reported increased brain activity associated with the unattend over the attend condition (Sabri et al. 2005), when odorants were not consciously perceived they had a greater effect on perception. The initial results obtained by Cowely et al. combined with numerous Type A studies (Cowley and Brooksbank 1991; Cutler et al. 1998; McCoy and Pitino 2002; Saxton et al. 2008), to suggest that subliminal odors can influence social judgments.

Subliminal odorants influence mood

That odorants can influence mood is of course a major tenet of aromatherapy, a rapidly growing industry (Herz 2009). Several lines of evidence suggest that subliminal odors indeed have the capacity to influence mood. For
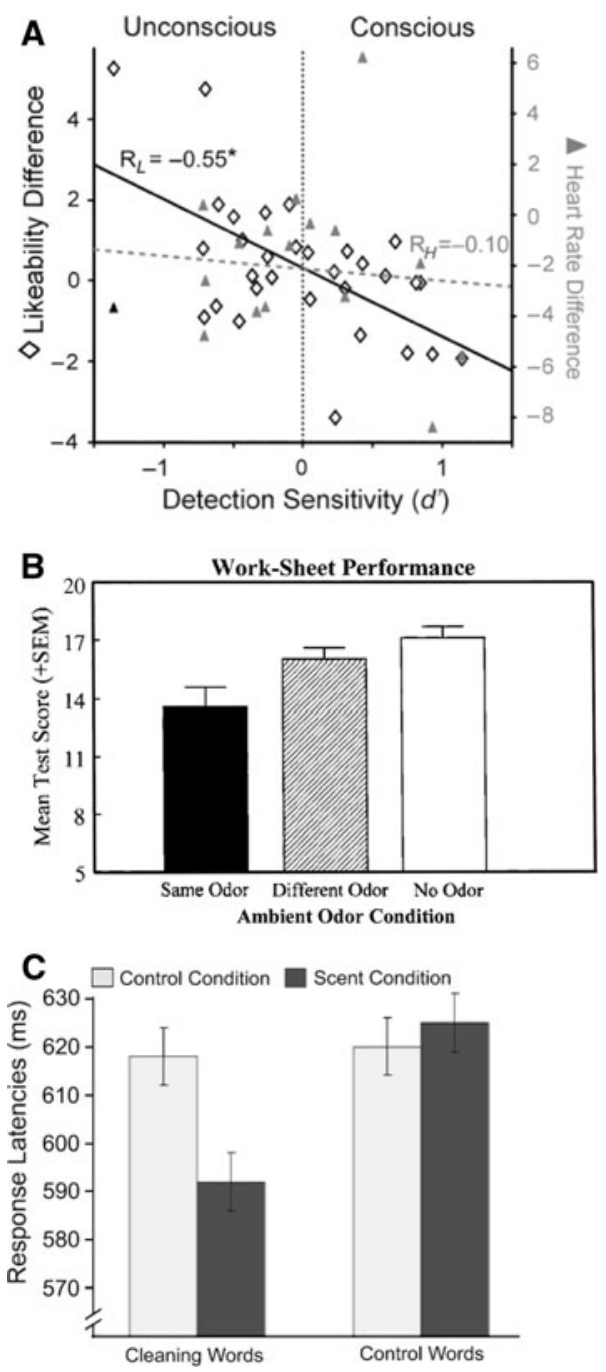

Fig. 6 The influence of subliminal odors a Results from Li et al. (2007). Increased odor awareness ( $x$ axis) was associated with a reduced influence on judgments ( $y$ axis). b Results from Epple and Herz (1999). Mean performance on a cognitive test by 5 -year old children as a function of odor condition. Participants in the "same odor" condition (an odor previously associated with a frustrating task) performed worse than participants in the "different odor" or "no odor" groups $(P<0.05)$. c Results from Holland et al. (2005). Mean reaction times for cleaning related words and control words in odor and control conditions (without an odor) during a lexical decision task. Participants responded faster to cleaning-related words than to control words $(P<0.05)$, and excluding participants that have been aware of the odor, revealed a significant interaction between odor presence and word type $(P<0.05)$

example, dispersing an orange scent in a dentist's waiting room had a host of positive effects on women's but not men's mood (Lehrner et al. 2000). The authors attributed the observed gender difference to the different olfactory sensitivity across genders. In an additional study, experimenters diffused either a pleasant or unpleasant odorant in a room where subjects completed various questionnaires. Each subject participated twice, once with an odorant diffused, and once without (Knasko 1995). The authors 
found that whereas the pleasant odorant (lavender or lemon) had no influence in this instance, the unpleasant odorant (dimethyl sulfide) negatively impacted mood. Furthermore, subjects who experienced the unpleasant odor in their first session had reduced mood in their second session even when it was odorless. This suggests an implicit odorant-induced conditioning of mood. Indeed, several studies have replicated this effect. For example, undetected levels of the odorant Trimethylundecylenic aldehyde induced anxiety in women who had previously been exposed to similarly undetected levels of the odorant during a stressful task. Critically, this anxiety was not the result of the odorant alone, as participants in the stressful task that was conducted without odor were in fact soothed by the odorant when presented later (Kirk-Smith et al. 1983). This core finding was later replicated independently (Zucco et al. 2009). Finally, a large body of Type A studies examined the mood influences of compounds present in sweat (Chen and Haviland-Jones 1999, 2000; Grosser et al. 2000; Jacob et al. 2001a; Bensafi et al. 2004; Lundstrom and Olsson 2005). Whereas these studies were typically Type A studies, critically, one study revealed that these effects replicated across detectable and undetectable concentrations of the odorant (Lundstrom et al. 2003).

Subliminal odorants influence cognitive performance

A Type B study that revealed cognitive influences of subliminal odors was conducted in children. Five-year-old children were engaged in a frustrating maze-solving task in the presence of undetected odor. Following the maze task, subjects participated in a challenging cognitive task that was held in another room in the presence of either the same odor, a different odor, or no odor. Children who were exposed to the same odor in the maze and cognitive tasks obtained significantly lower scores than children in the no or different odor groups (Epple and Herz 1999) (Fig. 6b). These studies combined with numerous Type A studies (Chen et al. 2006; Hummer and McClintock 2009) to suggest that subliminal odors can influence cognitive performance. In one such Type A example, smelling androstadienone led women to the feeling of being focused without detecting the presence of the compound (Lundstrom et al. 2003).

\section{Subliminal odorants influence behavior}

In an early Type B experiment that studied behavior, researchers sprayed one of three different concentrations of the odorant androstenone on a seat in a dentist's waiting room. They found that the high concentration of androstenone repelled men and attracted women to sit on that particular chair (Kirk-Smith and Booth 1980).
In a more recent study, researchers scented the experimental room with a citrus odor typical of cleaning fluids. They found that participants responded faster to cleaning than to non-cleaning related words in a lexical decision task, reported more near future plans involving cleaning activities, and in fact generated more actual cleaning behavior while eating (Holland et al. 2005) (Fig. 6c).

The possibility of subliminally influencing behavior with odors has not gone unnoticed by the consumer industry (Spangenberg et al. 2006). For example, men evaluated magazines more positively under exposure to the odorant androstenol (Ebster and Kirk-Smith 2005). Ambient scent spread in a mall increased the amount of money spent by young shoppers (Chebat et al. 2009), positively influenced shoppers' perceptions (Michon et al. 2005) as well as brand appreciation and memory (Morrin and Ratneshwar 2003), and increased both the time and amount of money spent in a restaurant (GuÈguen and Petr 2006). Furthermore, dispersal of one odor, but not another in the surroundings of casino slot machines increased the sums of money spent in those machines (Hirsch 1995). These studies combined with numerous Type A studies (Gustavson et al. 1987; Cowley and Brooksbank 1991; Cutler et al. 1998; McCoy and Pitino 2002; Castiello et al. 2006; Tubaldi et al. 2008a, b, 2009) to suggest that subliminal odors can influence behavior.

\section{A time-stamp dissociating subliminal from perceived olfactory stimuli}

Electrical recordings of odorant dependent neural activity in humans reveal several typical time-points. Brain activity recorded by OERP and OMEG (olfactory magnetoencephalogram) revealed a typical response pattern consisting of a negative component (N1) at 320-500 ms, a positive component (P2) at 450-700, a second negative component (N2) at $600-900 \mathrm{~ms}$, and a second positive component (P3) at 750-1,200 ms after stimulus onset (Pause et al. 1996, 1997; Morgan et al. 1999; Walla et al. 2002; Harada et al. 2003; Rombaux et al. 2006; Walla 2008).

It is generally accepted that the first two components, parietal $\mathrm{N} 1$ and frontal $\mathrm{P} 2$, reflect exogenous modulators such as stimulus concentration, whereas the late parietal positive component $\mathrm{P} 3$ represents endogenous modulators such as subjective stimulus significance and stimulus probability (Pause et al. 1996). Explicitly attending to the odorant increased the amplitude of P3 only (main effect across all three electrodes (Fz, Cz and Pz)) (Pause et al. 1997). Furthermore, comparing OEMG responses between subjects that perceived an odor and subjects that did not, revealed that whereas the early 200-500 ms response components were identical across groups, the late 600-900 ms 
response components were associated with conscious perception (Walla et al. 2002). Together, these findings suggest a two-stage olfactory process containing mechanisms without awareness that enact within $\sim 200 \mathrm{~ms}$ post stimulus onset, and mechanisms of awareness within $\sim 600 \mathrm{~ms}$ post stimulus onset (Walla 2008).

In that olfactory awareness may have a time-stamp, it is tempting to then link this temporally localized activity to an anatomical substrate. Despite the theoretically high spatial resolution of MEG, Walla et al. (2002) did not clearly assign the late component to a particular brain region. Previous MEG studies, unrelated to attentional manipulations, have assigned a 300-500 ms component to anterior central parts of the insula (Kettenmann et al. 1997), and a 500-700 ms component to the superior temporal sulcus, but comprehensive anatomical pin-pointing of this source remains unavailable. Various theoretical considerations have implied locating olfactory awareness to primary or secondary olfactory cortex (Smythies 1997; Shepherd 2007), but this question remains unresolved.

\section{Conclusions}

We reviewed evidence suggesting that humans have superb olfactory abilities, yet olfaction has a limited place in human awareness. We attributed this apparent paradox to the facts that odors are poorly localized in space, and are far separated in time, and this combination renders odors a poor substrate for selective attention. Reduced applicability of selective attention may combine with a theorized inhibitory mechanism (Sobel and Brown 2001) and additional factors (Stevenson 2009b) to jointly limit the place of odors in awareness. Critically, when human spatial and temporal processing of vision and audition are damaged by lesions such that they are then comparable to the spatial and temporal aspects of intact human olfaction, these lesions are accompanied by a loss of awareness (Deouell et al. 2000; Deouell 2002). This suggests that the mechanisms we have proposed are not unique to olfaction, but rather unique and representative of brain mechanisms for awareness.

Finally, it is noteworthy that the two mechanisms of olfaction considered in this review are very different in macrosmatic mammals. Most mammals likely do have egocentric spatial abilities in olfaction (Rajan et al. 2006), and sniff at a frequency that may prevent change-blindness (Welker 1964). These differences may allow a form of olfactory awareness in macrosmatic mammals that is unavailable to humans. Thus, whereas human olfactory perception is dominated by the perceptual axis of odorant pleasantness to an extent that renders it nearly unidimensional (Yeshurun and Sobel 2010), the mechanisms we have highlighted here may allow macrosmatic olfactory perception that is far richer. All this, however, does not limit the influence of odors on human perception and behavior, both of which may in fact be more susceptible to the influence of subliminal than perceived smells (Fig. 6a).

Acknowledgments The work in our lab is funded by an ERC FP7 grant \#200850, and by the James S. McDonnell foundation. We Thank Arak Elite and Assaf Rotman for Figs. 4 and 5 etc.

Open Access This article is distributed under the terms of the Creative Commons Attribution Noncommercial License which permits any noncommercial use, distribution, and reproduction in any medium, provided the original author(s) and source are credited.

\section{References}

Abrams RA, Christ SE (2003) Motion onset captures attention. Psychol Sci 14:427-432

Ache BW, Young JM (2005) Olfaction: diverse species, conserved principles. Neuron 48:417-430

Ackerl K, Atzmueller M, Grammer K (2002) The scent of fear. Neuro Endocrinol Lett 23:79-84

Adrian ED (1942) Olfactory reactions in the brain of the hedgehog. J Physiol 100:459-473

AMA (1993) Guides to the evaluation of permanent impairment. American Medical Association, Chicago

Auvray M, Gallace A, Hartcher-O'Brien J, Tan HZ, Spence C (2008) Tactile and visual distractors induce change blindness for tactile stimuli presented on the fingertips. Brain Res 1213:111-119

Barnes DC, Hofacer RD, Zaman AR, Rennaker RL, Wilson DA (2008) Olfactory perceptual stability and discrimination. Nat Neurosci 11:1378-1380

Békésy GV (1964) Olfactory analogue to directional hearing. J Appl Physiol 19:369-373

Bende M, Nordin S (1997) Perceptual learning in olfaction: professional wine tasters versus controls. Physiol Behav 62:1065-1070

Bensafi M, Brown WM, Khan R, Levenson B, Sobel N (2004) Sniffing human sex-steroid derived compounds modulates mood, memory and autonomic nervous system function in specific behavioral contexts. Behav Brain Res 152:11-22

Breer H, Fleischer J, Strotmann J (2006) The sense of smell: multiple olfactory subsystems. Cell Mol Life Sci 63:1465-1475

Bregman A (1990) Auditory scene analysis. MIT Press, Massachusetts

Broadbend DE (1958) Perception and communication. Pergamon Press, London

Buck L, Axel R (1991) A novel multigene family may encode odorant receptors: a molecular basis for odor recognition. Cell 65:175-187

Burr DC, Morrone MC, Ross J (1994) Selective suppression of the magnocellular visual pathway during saccadic eye movements. Nature 371:511-513

Caffier PP, Erdmann U, Ullsperger P (2003) Experimental evaluation of eye-blink parameters as a drowsiness measure. Eur J Appl Physiol 89:319-325

Cain WS (1977) Differential sensitivity for smell: "noise" at the nose. Science 195:796-798

Cain WS, Gent JF (1991) Olfactory sensitivity: reliability, generality, and association with aging. J Exp Psychol Hum Percept Perform 17:382-391

Cain WS, Stevens JC (1989) Uniformity of olfactory loss in aging. Ann N Y Acad Sci 561:29-38

Cain WS, Schmidt R, Wolkoff P (2007) Olfactory detection of ozone and D-limonene: reactants in indoor spaces. Indoor Air 17:337347 
Castiello U, Zucco GM, Parma V, Ansuini C, Tirindelli R (2006) Cross-modal interactions between olfaction and vision when grasping. Chem Senses 31:665-671

Cernoch JM, Porter RH (1985) Recognition of maternal axillary odors by infants. Child Dev 56:1593-1598

Chebat JC, Morrin M, Chebat DR (2009) Does age attenuate the impact of pleasant ambient scent on consumer response? Environ Behav 41:258

Chen D, Haviland-Jones J (1999) Rapid mood change and human odors. Physiol Behav 68:241-250

Chen D, Haviland-Jones J (2000) Human olfactory communication of emotion. Percept Mot Skills 91:771-781

Chen D, Katdare A, Lucas N (2006) Chemosignals of fear enhance cognitive performance in humans. Chem Senses 31:415-423

Cherry EC (1953) Some experiments on the recognition of speech, with one and two ears. J Acoust Soc Am 25:975-979

Choudhury ES, Moberg P, Doty RL (2003) Influences of age and sex on a microencapsulated odor memory test. Chem Senses 28:799-805

Classen C, Howes D, Synnott A (1994) Aroma: the cultural history of smell. Routledge, New York

Corbetta M, Shulman GL (2002) Control of goal-directed and stimulus-driven attention in the brain. Nat Rev Neurosci 3:201-215

Cowley JJ, Brooksbank BW (1991) Human exposure to putative pheromones and changes in aspects of social behaviour. J Steroid Biochem Mol Biol 39:647-659

Cowley JJ, Johnson AL, Brooksbank BW (1977) The effect of two odorous compounds on performance in an assessment-of-people test. Psychoneuroendocrinol 2:159-172

Cross DJ, Flexman JA, Anzai Y, Morrow TJ, Maravilla KR, Minoshima S (2006) In vivo imaging of functional disruption, recovery and alteration in rat olfactory circuitry after lesion. Neuroimage 32:1265-1272

Cutler WB, Friedmann E, McCoy NL (1998) Pheromonal influences on sociosexual behavior in men. Arch Sex Behav 27:1-13

Dalton P, Doolittle N, Breslin PA (2002) Gender-specific induction of enhanced sensitivity to odors. Nat Neurosci 5:199-200

de Araujo IE, Rolls ET, Velazco MI, Margot C, Cayeux I (2005) Cognitive modulation of olfactory processing. Neuron 46:671-679

Demany L, Trost W, Serman M, Semal C (2008) Auditory change detection: simple sounds are not memorized better than complex sounds. Psychol Sci 19:85-91

Deouell LY (2002) Pre-requisites for conscious awareness: clues from electrophysiological and behavioral studies of unilateral neglect patients. Conscious Cog 11:546-567

Deouell LY, Bentin S, Soroker N (2000) Electrophysiological evidence for an early (pre-attentive) information processing deficit in patients with right hemisphere damage and unilateral neglect. Brain 123:353-365

Deouell LY, Heller AS, Malach R, D’Esposito M, Knight RT (2007) Cerebral responses to change in spatial location of unattended sounds. Neuron 55:985-996

DeValois RL, DeValois KK (2002) Spatial vision. In: Ramachandran VS (ed) Encyclopedia of the human brain, vol 4. Academic Press, New York, pp 419-431

Doty RL (1995) Intranasal trigeminal chemoreception: anatomy, physiology, and psychophysics. In: Doty RL (ed) Handbook of olfaction and gustation. Marcel Dekker, Inc., New York, pp 821-834

Doty RL (2003) Mammalian pheromones: fact or fantasy? In: Doty RL (ed) Handbook of olfaction and gustation. Marcel Dekker, Inc., New York, pp 345-383

Driver J, Grossenbacher PG (1996) Multimodal spatial constraints on tactile selective attention. In: Inui T, McClelland JL (eds) Attention and performance XVI: information integration in perception and communication. MIT Press, Cambridge, pp 209-235

Driver J, Spence CJ (2004) Rossmodal spatial attention: evidence from human performance. In: Spence CJ, Driver J (eds) Rossmodal space and crossmodal attention. Oxford University Press, Oxford, pp 179-220

Dubose C, Cardello A, Maller O (1980) Effects of colorants and flavorants on identification, perceived flavor intensity, and hedonic quality of fruit-flavored beverages and cake. J Food Sci 45:13931399

Ebster C, Kirk-Smith M (2005) The effect of the human pheromone androstenol on product evaluation. Psychol Market 22:739

Engen T (1972) The effect of expectation on judgments of odor. Acta Psychol (Amst) 36:450-458

Engen T, Bosack TN (1969) Facilitation in olfactory detection. J Comp Physiol Psychol 68:320-326

Epple G, Herz RS (1999) Ambient odors associated to failure influence cognitive performance in children. Dev Psychobiol 35:103-107

Eramudugolla R, Irvine DR, McAnally KI, Martin RL, Mattingley JB (2005) Directed attention eliminates 'change deafness' in complex auditory scenes. Curr Biol 15:1108-1113

Fechner A, Fong S, McGovern P (2008) A review of Kallmann syndrome: genetics, pathophysiology, and clinical management. Obstet Gynecol Sur 63:189-194

Fleischer J, Schwarzenbacher K, Besser S, Hass N, Breer H (2006) Olfactory receptors and signalling elements in the Grueneberg ganglion. J Neurochem 98:543-554

Frasnelli J, Charbonneau G, Collignon O, Lepore F (2009) Odor localization and sniffing. Chem Senses 34:139-144

Fritz JB, Elhilali M, David SV, Shamma SA (2007) Auditory attention-focusing the searchlight on sound. Curr Opin Neurobiol 17:437-455

Gallace A, Tan HZ, Spence C (2006) The failure to detect tactile change: a tactile analogue of visual change blindness. Psychon Bull Rev 13:300-303

Geisler MW, Murphy C (2000) Event-related brain potentials to attended and ignored olfactory and trigeminal stimuli. Int J Psychophysiol 37:309-315

Gilad Y, Lancet D (2003) Population differences in the human functional olfactory repertoire. Mol Biol Evol 20:307-314

Goldman AL, Van der Goes van Naters W, Lessing D, Warr CG, Carlson JR (2005) Coexpression of two functional odor receptors in one neuron. Neuron 45:661-666

Grabenhorst F, Rolls ET (2008) Selective attention to affective value alters how the brain processes taste stimuli. Eur J Neurosci 27:723-729

Graziadei PP, Monti Graziadei AG (1983) Regeneration in the olfactory system of vertebrates. Am J Otolaryngol 4:228-233

Grosmaitre X, Santarelli LC, Tan J, Luo M, Ma M (2007) Dual functions of mammalian olfactory sensory neurons as odor detectors and mechanical sensors. Nat Neurosci 10:348-354

Grosmaitre X, Fuss SH, Lee AC, Adipietro KA, Matsunami H, Mombaerts P, Ma M (2009) SR1, a mouse odorant receptor with an unusually broad response profile. J Neurosci 29:14545-14552

Grosser BI, Monti-Bloch L, Jennings-White C, Berliner DL (2000) Behavioral and electrophysiological effects of androstadienone, a human pheromone. Psychoneuroendocrinol 25:289-299

GuÈguen N, Petr C (2006) Odors and consumer behavior in a restaurant. Inter J Hosp Man 25:335-339

Gulyas B, Keri S, O'Sullivan BT, Decety J, Roland PE (2004) The putative pheromone androstadienone activates cortical fields in the human brain related to social cognition. Neurochem Inter 44:595-600

Gustavson AR, Dawson ME, Bonett DG (1987) Androstenol, a putative human pheromone, affects human (Homo sapiens) male choice performance. J Comp Psychol 101:210-212

Haddad R, Khan R, Takahashi YK, Mori K, Harel D, Sobel N (2008a) A metric for odorant comparison. Nat Methods 5:425-429

Haddad R, Lapid H, Harel D, Sobel N (2008b) Measuring smells. Curr Opin Neurobiol 18:438-444 
Hafter ER (1984) Spatial hearing and the duplex theory: how viable is the model? In: Edelman GM, Gall WE, Cowan WM (eds) Dynamic aspects of neocortical function. Wiley, New York, pp 425-448

Hallem EA, Carlson JR (2006) Coding of odors by a receptor repertoire. Cell 125:143-160

Harada H, Shiraishi K, Kato T (2003) Olfactory event-related potentials in normal subjects and patients with smell disorders. Clin Electroencephalogr 34:191-196

Heilmann S, Hummel T (2004) A new method for comparing orthonasal and retronasal olfaction. Behav Neurosci 118:412-419

Herz RS (2009) Aromatherapy facts and fictions: a scientific analysis of olfactory effects on mood, physiology and behavior. Int J Neurosci 119:263-290

Hirsch AR (1995) Effects of ambient odors on slot-machine usage in a Las Vegas casino. Psychol Market 12:585-594

Holland RW, Hendriks M, Aarts H (2005) Smells like clean spirit. Nonconscious effects of scent on cognition and behavior. Psychol Sci 16:689-693

Howard JD, Plailly J, Grueschow M, Haynes JD, Gottfried JA (2009) Odor quality coding and categorization in human posterior piriform cortex. Nat Neurosci 12:932-938

Hulshoff Pol HE, Hijman R, Baare WF, van Eekelen S, van Ree JM (2000) Odor discrimination and task duration in young and older adults. Chem Senses 25:461-464

Hummel T, Guel H, Delank W (2004) Olfactory sensitivity of subjects working in odorous environments. Chem Senses 29:533-536

Hummel T, Heilmann S, Landis BN, Redem J, Frasnelli J, Smal DM, Gerber J (2006a) Perceptual differences between chemical stimuli presented through the ortho- or retronasal route. Flav Frag J 21:42-47

Hummel T, Mojet J, Kobal G (2006b) Electro-olfactograms are present when odorous stimuli have not been perceived. Neurosci Lett 397:224-228

Hummer TA, McClintock MK (2009) Putative human pheromone androstadienone attunes the mind specifically to emotional information. Horm Behav 55:548-559

Jacob S, Hayreh DJ, McClintock MK (2001a) Context-dependent effects of steroid chemosignals on human physiology and mood. Physiol Behav 74:15-27

Jacob S, Kinnunen LH, Metz J, Cooper M, McClintock MK (2001b) Sustained human chemosignal unconsciously alters brain function. Neuroreport 12:2391-2394

James W (1890) The principles of psychology. Cosimo, New York

Jehl C, Royet JP, Holley A (1995) Odor discrimination and recognition memory as a function of familiarization. Percept Psychophys 57:1002-1011

Kaluza JF, Gussing F, Bohm S, Breer H, Strotmann J (2004) Olfactory receptors in the mouse septal organ. J Neurosci Res 76:442-452

Karlson P, Luscher M (1959) "Pheromones": a new term for a class of biologically active substances. Nature 183:55-56

Keller A, Zhuang H, Chi Q, Vosshall LB, Matsunami H (2007) Genetic variation in a human odorant receptor alters odour perception. Nature 449:468-472

Kepecs A, Uchida N, Mainen ZF (2006) The sniff as a unit of olfactory processing. Chem Senses 31:167-179

Kettenmann B, Hummel C, Stefan H, Kobal G (1997) Multiple olfactory activity in the human neocortex identified by magnetic source imaging. Chem Senses 22:493-502

Keverne EB (1999) The vomeronasal organ. Science 286:716-720

Kirk-Smith MD, Booth DA (1980) Effect of androstenone on choice of location in others' presence. In: International symposium on olfaction and taste VII, vol olfaction and taste VII. IRL Press Limited, Noordwijkerhout, Netherlands, pp 397-400

Kirk-Smith MD, Van Toller C, Dodd GH (1983) Unconscious odour conditioning in human subjects. Biol Psychol 17:221-231
Klatzky R (1998) Allocentric and egocentric spatial representations: definitions, distinctions, and interconnections. Lect Notes Comput Sci 1404:1-17

Knaapila A, Tuorila H, Kyvik KO, Wright MJ, Keskitalo K, Hansen J, Kaprio J, Perola M, Silventoinen K (2008) Self-ratings of olfactory function reflect odor annoyance rather than olfactory acuity. Laryngoscope 118:2212-2217

Knasko SC (1995) Pleasant odors and congruency: effects on approach behavior. Chem Senses 20:479-487

Kobal G, Van Toller S, Hummel T (1989) Is there directional smelling? Experientia 45:130-132

Koelega HS, Koster EP (1974) Some experiments on sex differences in odor perception. Ann N Y Acad Sci 237:234-246

Krauel K, Pause BM, Sojka B, Schott P, Ferstl R (1998) Attentional modulation of central odor processing. Chem Senses 23:423-432

Krauel K, Schott P, Sojka B, Pause BM, Ferstl R (1999) Is there a mismatch negativity analogue in the olfactory event-related potential? J Psychophysiol 13:49-55

Laing DG (1983) Natural sniffing gives optimum odour perception for humans. Perception 12:99-117

Laing DG, Francis GW (1989) The capacity of humans to identify odors in mixtures. Physiol Behav 46:809-814

Laing DG, Glemarec A (1992) Selective attention and the perceptual analysis of odor mixtures. Physiol Behav 52:1047-1053

Landis BN, Hummel T, Hugentobler M, Giger R, Lacroix JS (2003) Ratings of overall olfactory function. Chem Senses 28:691-694

Laska M, Freyer D (1997) Olfactory discrimination ability for aliphatic esters in squirrel monkeys and humans. Chem Senses 22:457-465

Laska M, Liesen A, Teubner P (1999) Enantioselectivity of odor perception in squirrel monkeys and humans. Am J Physiol Regul Integr Comp Physiol 277:R1098-R1103

Laska M, Ayabe-Kanamura S, Hubener F, Saito S (2000) Olfactory discrimination ability for aliphatic odorants as a function of oxygen moiety. Chem Senses 25:189-197

Le Berre E, Beno N, Ishii A, Chabanet C, Etievant P, Thomas-Danguin $\mathrm{T}$ (2008) Just noticeable differences in component concentrations modify the odor quality of a blending mixture. Chem Senses 33:389-395

Lehrner J, Eckersberger C, Walla P, Potsch G, Deecke L (2000) Ambient odor of orange in a dental office reduces anxiety and improves mood in female patients. Physiol Behav 71:83-86

Leon M, Johnson BA (2003) Olfactory coding in the mammalian olfactory bulb. Brain Res Brain Res Rev 42:23-32

Li W, Luxenberg E, Parrish T, Gottfried JA (2006) Learning to smell the roses: experience-dependent neural plasticity in human piriform and orbitofrontal cortices. Neuron 52:1097-1108

Li W, Moallem I, Paller KA, Gottfried JA (2007) Subliminal smells can guide social preferences. Psychol Sci 18:1044-1049

Li W, Howard JD, Parrish TB, Gottfried JA (2008) Aversive learning enhances perceptual and cortical discrimination of indiscriminable odor cues. Science 319:1842-1845

Livermore A, Laing DG (1996) Influence of training and experience on the perception of multicomponent odor mixtures. J Exp Psychol Hum Percept Perform 22:267-277

Lord T, Kasprzak M (1989) Identification of self through olfaction. Percept Mot Skills 69:219-224

Lorig T (1992) Cognitive and 'non-cognitive' effects of odor exposure: electrophysiological and behavioral evidence. In: Van Toller S, Dodd G (eds) The psychology and biology of perfume. Elsevier, Amsterdam, pp 161-173

Lundstrom JN, Olsson MJ (2005) Subthreshold amounts of social odorant affect mood, but not behavior, in heterosexual women when tested by a male, but not a female, experimenter. Biol Psychol 70:197-204

Lundstrom JN, Goncalves M, Esteves F, Olsson MJ (2003) Psychological effects of subthreshold exposure to the putative human 
pheromone 4, 16-androstadien-3-one. Horm Behav 44:395401

Lundstrom JN, Boyle JA, Zatorre RJ, Jones-Gotman M (2008) The neuronal substrates of human olfactory based kin recognition. Hum Brain Mapp 30:2571-2580

Macfarelane A (1975) Olfaction in the development of social preferences in the human neonate. Ciba Found Symp 33:103-117

Madan R, Sawlani V, Gupta S, Phadke RV (2004) MRI findings in Kallmann syndrome. Neurol India 52:501-503

Mainen ZF (2006) Behavioral analysis of olfactory coding and computation in rodents. Curr Opin Neurobiol 16:429-434

Mainland J, Sobel N (2006) The sniff is part of the olfactory percept. Chem Senses 31:181-196

Mainland JD, Bremner EA, Young N, Johnson BN, Khan RM, Bensafi M, Sobel N (2002) Olfactory plasticity: one nostril knows what the other learns. Nature 419:802

Mallet P, Schaal B (1998) Rating and recognition of peers' personal odors by 9 -year-old children: an exploratory study. J Gen Psychol $125: 47-64$

Malnic B, Hirono J, Sato T, Buck LB (1999) Combinatorial receptor codes for odors. Cell 96:713-723

Maresh A, Rodriguez Gil D, Whitman MC, Greer CA (2008) Principles of glomerular organization in the human olfactory bulbimplications for odor processing. PLoS One 3:e2640

McBride SA, Slotnick B (1997) The olfactory thalamocortical system and odor reversal learning examined using an asymmetrical lesion paradigm in rats. Behav Neurosci 111:1273-1284

McClintock MK (1971) Menstrual synchrony and suppression. Nature 229:244-245

McCoy NL, Pitino L (2002) Pheromonal influences on sociosexual behavior in young women. Physiol Behav 75:367-375

Melcher JM, Schooler JW (1996) The misremembrance of wines past: verbal and perceptual expertise differentially mediate verbal overshadowing of taste memory. J Mem Lang 35:231-245

Meredith M (2001) Human vomeronasal organ function: a critical review of best and worst cases. Chem Senses 26:433-445

Michon R, Chebat JC, Turley LW (2005) Mall atmospherics: the interaction effects of the mall environment on shopping behavior. J Bus Res 58:576-583

Moran DT, Rowley JC, Jafek BW, Lovell MA (1982) The fine-structure of the olfactory mucosa in man. J Neurocytol 11:721-746

Morgan CD, Geisler MW, Covington JW, Polich J, Murphy C (1999) Olfactory P3 in young and older adults. Psychophysiology 36:281-287

Morrin M, Ratneshwar S (2003) Does it make sense to use scents to enhance brand memory? J Market Res 40:10-25

Morrot G, Brochet F, Dubourdieu D (2001) The color of odors. Brain Lang 79:309-320

Murphy C, Schubert CR, Cruickshanks KJ, Klein BE, Klein R, Nondahl DM (2002) Prevalence of olfactory impairment in older adults. Jama 288:2307-2312

Nagata Y (2003) Measurement of odor threshold by triangle odor bag method. Odor measurement review, Japan Ministry of the Environment, pp 118-127

Nagata Y, Takeuchi N (1990) Measurement of odor threshold by triangle odor bag method. Bull Jpn Environ Sanit Center 17:77-89

Parr WV, Heatherbell D, White KG (2002) Demystifying wine expertise: olfactory threshold, perceptual skill and semantic memory in expert and novice wine judges. Chem Senses 27:747-755

Pause BM, Sojka B, Krauel K, Ferstl R (1996) The nature of the late positive complex within the olfactory event-related potential (OERP). Psychophysiology 33:376-384

Pause BM, Sojka B, Ferstl R (1997) Central processing of odor concentration is a temporal phenomenon as revealed by chemosensory event-related potentials (CSERP). Chem Senses 22:9-26
Philpott CM, Wolstenholme CR, Goodenough PC, Clark A, Murty GE (2006) Comparison of subjective perception with objective measurement of olfaction. Otolaryngol Head Neck Surg 134:488-490

Plailly J, Howard JD, Gitelman DR, Gottfried JA (2008) Attention to odor modulates thalamocortical connectivity in the human brain. J Neurosci 28:5257-5267

Porter RH, Moore JD (1981) Human kin recognition by olfactory cues. Physiol Behav 27:493-495

Porter RH, Cernoch JM, McLaughlin FJ (1983) Maternal recognition of neonates through olfactory cues. Physiol Behav 30:151-154

Porter J, Anand T, Johnson B, Khan RM, Sobel N (2005) Brain mechanisms for extracting spatial information from smell. Neuron 47:581-592

Porter J, Craven B, Khan RM, Chang SJ, Kang I, Judkewicz B, Volpe J, Settles G, Sobel N (2007) Mechanisms of scent-tracking in humans. Nat Neurosci 10:27-29

Posner MI, Petersen SE (1990) The attention system of the human brain. Annu Rev Neurosci 13:25-42

Posner MI, Snyder CR, Davidson BJ (1980) Attention and the detection of signals. J Exp Psychol 109:160-174

Preti G, Wysocki CJ, Barnhart KT, Sondheimer SJ, Leyden JJ (2003) Male axillary extracts contain pheromones that affect pulsatile secretion of luteinizing hormone and mood in women recipients. Biol Reprod 68:2107-2113

Price JL (1990) Olfactory system. In: Paxinos G (ed) The human nervous system. Academic Press, San Diego, pp 979-1001

Rabin MD (1988) Experience facilitates olfactory quality discrimination. Percept Psychophys 44:532-540

Radil T, Wysocki CJ (1998) Spatiotemporal masking in pure olfaction. Ann N Y Acad Sci 855:641-644

Rajan R, Clement JP, Bhalla US (2006) Rats smell in stereo. Science 311:666-670

Rawson NE (2006) Olfactory loss in aging. Sci Aging Knowl Environ 5:pe6

Remington R, Johnston J, Y antis S (1992) Involuntary attentional capture by abrupt onsets. Percep Psychophy 51:279-290

Rensink RA, O'Regan JK, Clark JJ (1997) To see or not to see: the need for attention to perceive changes in scenes. Psychol Sci 8:368-373

Robin DA, Rizzo M (1992) Orienting attention in audition and between audition and vision-young and elderly subjects. J Speech Hear Res 35:701-707

Rombaux P, Mouraux A, Bertrand B, Guerit JM, Hummel T (2006) Assessment of olfactory and trigeminal function using chemosensory event-related potentials. Neurophysiol Clin 36:53-62

Russell MJ, Switz GM, Thompson K (1980) Olfactory influences on the human menstrual cycle. Pharmacol Biochem Behav 13:737-738

Sabri M, Radnovich AJ, Li TQ, Kareken DA (2005) Neural correlates of olfactory change detection. Neuroimage 25:969-974

Saito H, Chi Q, Zhuang H, Matsunami H, Mainland JD (2009) Odor coding by a mammalian receptor repertoire. Sci Signal 2:ra9

Salmi J, Rinne T, Degerman A, Salonen O, Alho K (2007) Orienting and maintenance of spatial attention in audition and vision: multimodal and modality-specific brain activations. Brain Struct Funct 212:181-194

Savic I (2002) Sex differentiated hypothalamic activation by putative pheromones. Mol Psychiatry 7:335-336

Savic I, Gulyas B (2000) PET shows that odors are processed both ipsilaterally and contralaterally to the stimulated nostril. Neuroreport 11:2861-2866

Savic I, Berglund H, Gulyas B, Roland P (2001) Smelling of odorous sex hormone-like compounds causes sex-differentiated hypothalamic activations in humans. Neuron 31:661-668

Savic I, Berglund H, Lindstrom P (2005) Brain responses to putative pheromones in homosexual men. Proc Natl Acad Sci USA 102:7356-7361 
Saxton T, Lyndon A, Little AC, Roberts C (2008) Evidence that androstadienone, a putative human chemosignal, modulates women's attributions of men's attractiveness. Horm Behav 54:597-601

Schaal B, Montagner H, Hertling E, Bolzoni D, Moyse A, Quichon R (1980) Olfactory stimulations in mother-child relations. Rep Nut Dev 20:843-858

Schneider RA, Schmidt CE (1967) Dependency of olfactory localization on non-olfactory cues. Physiol Behav 2:305-309

Schoenfeld TA, Cleland TA (2006) Anatomical contributions to odorant sampling and representation in rodents: zoning in on sniffing behavior. Chem Senses 31:131-144

Scott JW (2006) Sniffing and spatiotemporal coding in olfaction. Chem Senses 31:119-130

Sela L, Sacher Y, Serfaty C, Yeshurun Y, Soroker N, Sobel N (2009) Spared and impaired olfactory abilities after thalamic lesions. J Neurosci 29:12059-12069

Shepherd GM (2004) The human sense of smell: are we better than we think? PLoS Biol 2:E146

Shepherd GM (2007) Perspectives on olfactory processing, conscious perception, and orbitofrontal cortex. Ann N Y Acad Sci 1121:87101

Small DM, Gerber JC, Mak YE, Hummel T (2005) Differential neural responses evoked by orthonasal versus retronasal odorant perception in humans. Neuron 47:593-605

Smythies J (1997) The functional neuroanatomy of awareness: with a focus on the role of various anatomical systems in the control of intermodal attention. Conscious Cogn 6:455-481

Sobel N, Brown WM (2001) The scented brain: pheromonal responses in humans. Neuron 31:512-514

Sobel N, Prabhakaran V, Desmond JE, Glover GH, Goode RL, Sullivan EV, Gabrieli JD (1998a) Sniffing and smelling: separate subsystems in the human olfactory cortex. Nature 392:282-286

Sobel N, Prabhakaran V, Hartley CA, Desmond JE, Zhao Z, Glover GH, Gabrieli JD, Sullivan EV (1998b) Odorant-induced and sniffinduced activation in the cerebellum of the human. J Neurosci 18:8990-9001

Sobel N, Prabhakaran V, Hartley CA, Desmond JE, Glover GH, Sullivan EV, Gabrieli JD (1999) Blind smell: brain activation induced by an undetected air-borne chemical. Brain 122(Pt 2): 209-217

Solomon GEA (1990) Psychology of novice and expert wine talk. Am J Psychol 103:495-517

Spangenberg ER, Sprott DE, Grohmann B, Tracy DL (2006) Gendercongruent ambient scent influences on approach and avoidance behaviors in a retail store. J Bus Res 59:1281-1287

Spehr M, Munger SD (2009) Olfactory receptors: G protein-coupled receptors and beyond. J Neurochem 109:1570-1583

Spence C (2002) Multisensory attention and tactile information-processing. Behav Brain Res 135:57-64

Spence CJ, Driver J (1994) Covert spatial orienting in audition: exogenous and endogenous mechanisms. J Exp Psychol Hum Percept Perform 20:555-574

Spence C, McGlone FP, Kettenmann B, Kobal G (2001) Attention to olfaction. A psychophysical investigation. Exp Brain Res 138:432-437

Stern K, McClintock MK (1998) Regulation of ovulation by human pheromones. Nature 392:177-179

Stettler DD, Axel R (2009) Representations of odor in the piriform cortex. Neuron 63:854-864

Stevenson RJ (2009a) An initial evaluation of the functions of human olfaction. Chem Senses 35:3-20

Stevenson RJ (2009b) Phenomenal and access consciousness in olfaction. Conscious $\operatorname{Cog}$ 18:1004-1017

Stowers L, Marton TF (2005) What is a pheromone? Mammalian pheromones reconsidered. Neuron 46:699-702
Su CY, Menuz K, Carlson JR (2009) Olfactory perception: receptors, cells, and circuits. Cell 139:45-59

Tian H, Ma M (2004) Molecular organization of the olfactory septal organ. J Neurosci 24:8383-8390

Treisman AM, Gelade G (1980) A feature-integration theory of attention. Cogn Psychol 12:97-136

Tubaldi F, Ansuini C, Dematte ML, Tirindelli R, Castiello U (2008a) Effects of olfactory stimuli on arm-reaching duration. Chem Senses $33: 433-440$

Tubaldi F, Ansuini C, Tirindelli R, Castiello U (2008b) The grasping side of odours. Plos One 3:e1795

Tubaldi F, Ansuini C, Tirindelli R, Castiello U (2009) The effects of task-irrelevant olfactory information on the planning and the execution of reach-to-grasp movements. Chemosens Percept 2:25-31

Uva L, de Curtis M (2004) Polysynaptic olfactory pathway to the ipsiand contralateral entorhinal cortex mediated via the hippocampus. Neuroscience 130:249-258

Varendi H, Christensson K, Porter RH, Winberg J (1998) Soothing effect of amniotic fluid smell in newborn infants. Early Hum Dev 51:47-55

Veldhuizen MG, Bender G, Constable RT, Small DM (2007) Trying to detect taste in a tasteless solution: modulation of early gustatory cortex by attention to taste. Chem Senses 32:569-581

Verhagen JV, Wesson DW, Netoff TI, White JA, Wachowiak M (2007) Sniffing controls an adaptive filter of sensory input to the olfactory bulb. Nat Neurosci 10:631-639

Vitevitch MS (2003) Change deafness: the inability to detect changes between two voices. J Exp Psychol-Hum Percep Perform 29:333342

Walla P (2008) Olfaction and its dynamic influence on word and face processing: cross-modal integration. Prog Neurobiol 84:192-209

Walla P, Hufnagl B, Lehrner J, Mayer D, Lindinger G, Deecke L, Lang W (2002) Evidence of conscious and subconscious olfactory information processing during word encoding: a magnetoencephalographic (MEG) study. Brain Res Cogn Brain Res 14:309-316

Wang L, Chen L, Jacob T (2004) Evidence for peripheral plasticity in human odour response. J Physiol 554:236-244

Wayand JF, Levin DT, Varakin DA (2005) Inattentional blindness for a noxious multimodal stimulus. Am J Psychol 118:339-352

Wedekind C, Furi S (1997) Body odour preferences in men and women: do they aim for specific MHC combinations or simply heterozygosity? Proc Biol Sci 264:1471-1479

Welker WI (1964) Analysis of sniffing of the albino rat. Behaviour 22:223-244

Whisman M, Goetzinger J, Cotton F, Brinkman D (1978) Odorant evaluation: a study of ethanethiol and tetrahdrothiophene as warning agents in propane. Environ Sci Technol 12:1285-1288

Wilson HC (1992) A critical review of menstrual synchrony research. Psychoneuroendocrinology 17:565-591

Wilson DA (1997) Binaral interactions in the rat piriform cortex. J Neurophysiol 78:160-169

Witt M, Hummel T (2006) Vomeronasal versus olfactory epithelium: is there a cellular basis for human vomeronasal perception? Int Rev Cytol 248:209-259

Wyart C, Webster WW, Chen JH, Wilson SR, McClary A, Khan RM, Sobel N (2007) Smelling a single component of male sweat alters levels of cortisol in women. J Neurosci 27:1261-1265

Wysocki CJ, Gilbert AN (1989) National geographic smell survey. Effects of age are heterogenous. Ann N Y Acad Sci 561:12-28

Wysocki CJ, Preti G (2004) Facts, fallacies, fears, and frustrations with human pheromones. Anat Rec A Discov Mol Cell Evol Biol 281:1201-1211

Wysocki CJ, Dorries KM, Beauchamp GK (1989) Ability to perceive androstenone can be acquired by ostensibly anosmic people. Proc Natl Acad Sci USA 86:7976-7978 
Yee KK, Wysocki CJ (2001) Odorant exposure increases olfactory sensitivity: olfactory epithelium is implicated. Physiol Behav 72:705-711

Yeshurun Y, Sobel N (2010) An odor is not worth a thousand words: from multidimensional odors to unidimensional odor objects. Annu Rev Psychol 61:(219-241):C211-C215

Youngentob SL, Mozell MM, Sheehe PR, Hornung DE (1987) A quantitative analysis of sniffing strategies in rats performing odor detection tasks. Physiol Behav 41:59-69
Zelano C, Sobel N (2005) Humans as an animal model for systemslevel organization of olfaction. Neuron 48:431-454

Zelano C, Bensafi M, Porter J, Mainland J, Johnson B, Bremner E, Telles C, Khan R, Sobel N (2005) Attentional modulation in human primary olfactory cortex. Nat Neurosci 8:114-120

Zucco GM, Paolini M, Schaal B (2009) Unconscious odour conditioning 25 years later: revisiting and extending 'Kirk-Smith, Van Toller and Dodd'. Learn Motiv 40:364-375 